\title{
Diagnosis of genital herpes simplex virus infection in the clinical laboratory
}

Jérôme LeGoff ${ }^{*}$, Hélène Péré ${ }^{2,3}$ and Laurent Bélec ${ }^{2,3}$

\begin{abstract}
Since the type of herpes simplex virus (HSV infection affects prognosis and subsequent counseling, type-specific testing to distinguish HSV-1 from HSV-2 is always recommended. Although PCR has been the diagnostic standard method for HSV infections of the central nervous system, until now viral culture has been the test of choice for HSV genital infection. However, HSV PCR, with its consistently and substantially higher rate of HSV detection, could replace viral culture as the gold standard for the diagnosis of genital herpes in people with active mucocutaneous lesions, regardless of anatomic location or viral type. Alternatively, antigen detection - an immunofluorescence test or enzyme immunoassay from samples from symptomatic patients-could be employed, but HSV type determination is of importance. Type-specific serology based on glycoprotein $\mathrm{G}$ should be used for detecting asymptomatic individuals but widespread screening for HSV antibodies is not recommended. In conclusion, rapid and accurate laboratory diagnosis of HSV is now become a necessity, given the difficulty in making the clinical diagnosis of HSV, the growing worldwide prevalence of genital herpes and the availability of effective antiviral therapy.
\end{abstract}

Keywords: Herpes simplex virus, Genital herpes, Diagnosis

\section{Introduction}

\section{Key structure elements for diagnosis}

Herpes simplex virus type 1 (HSV-1) and type 2 (HSV-2) are large double-stranded DNA viruses of the Herpetoviridae family, alphaherpetovirinae sub-family [1]. HSV-1 and HSV-2 share a similar genome structure, with $40 \%$ of sequence homologies reaching $83 \%$ homology of their protein-coding regions, explaining numerous biological similarities and antigenic cross-reactivity between the two types. HSV-1 and HSV-2 genomes each encode at least 80 different structural and non-structural polypeptides including at least 10 different viral glycoproteins of which most are embedded in the viral envelope $(\mathrm{gB}, \mathrm{gC}$, $\mathrm{gD}, \mathrm{gE}, \mathrm{gG}, \mathrm{gH}, \mathrm{gI}, \mathrm{gL}, \mathrm{gM}, \mathrm{gN})$ [1]. The majority of the antibody response to HSV infection is raised against these surface glycoproteins. Glycoprotein $\mathrm{gB}, \mathrm{gC}, \mathrm{gD}$ and $\mathrm{gE}$ trigger potent immune responses. Some epitopes present on these glycoproteins are shared by HSV-1 and HSV-2, and are causing a significant degree of cross

\footnotetext{
* Correspondence: jerome.le-goff@sls.aphp.fr

'Université Paris Diderot, Sorbonne Paris Cité, Microbiology laboratory, Inserm U941, Hôpital Saint-Louis, APHP, 1 Avenue Claude Vellefaux, Paris 75010, France

Full list of author information is available at the end of the article
}

reactivity. However, no cross reactivity between glycoprotein gG1 in HSV-1 and gG2 in HSV-2 can be detected [2] which is why antibodies to this glycoprotein are used for type-discriminating serology. While the type common $\mathrm{gB}$ and $\mathrm{gD}$ display high similarity (85\%) the homology betweengG-1 and gG-2 is much lower, presenting an overall amino acids (aa) identity of $<30 \%$. The reason for this is that gG-1 of HSV-1 contains 238 aa, while gG-2 of HSV-2 comprises 699 aa [2]. Furthermore, the envelope glycoprotein G (gG-2) of HSV-2 is cleaved into a membrane-bound portion (mgG-2) and a secreted portion (sgG-2). However, the epitopes for the typespecific antibodies against mgG-2 are not located in the portion of mgG-2 which is lacking in gG-1 but in a region with aa similarity to gG-1. This sequence, located between aa 560 and 573 for HSV-2 gG and between aa 80 and 93 for HSV-1 gG, carries nine identical residues between gG-1 and mgG-2 and five type-specific residues that induce significant structural differences. This results in different exposure of key residues utilized for recognition and explains the lack of cross-reactivity [3].

Other similarities and differences between the genomes of HSV-1 and HSV-2 are used also for genera- or type- 
specific molecular assays, including genes coding for some envelope glycoproteins or the DNA polymerase. The conserved gene coding for DNA polymerase is often used for the detection or quantitation of both types and based on a few mismatches between HSV-1 and HSV-2 sequences which may also be used for typing $[4,5]$.

\section{Burden of genital herpes}

HSV-1 and HSV-2 are ubiquitous, affecting both urban and remote populations worldwide [6]. HSV-1 seroprevalence reaches 50 to $70 \%$ in developed countries and $100 \%$ in developing countries and HSV-2 seroprevalence varies from 10 to $40 \%$ and may reach $60-95 \%$ in HIV-infected individuals and female sex workers.

The classical pattern of HSV-1 and HSV-2 infections associated with oral or genital diseases, respectively, remains the rule in certain parts of the world such as sub-Saharan Africa where HSV-1 infection remains a mandatory community acquired disease in childhood, and HSV-2 infection a sexually transmitted infection (STI) in adults. In contrast, the differentiation of HSV-1 from HSV-2 based on anatomical site of infection is far from absolute in developed countries, the proportion of genital ulcers associated with HSV-1 infection has become predominant in some developed countries [6,7]. This is the result of both the delay in acquisition of oral HSV-1 infection early in life in developed countries (rendering a significant proportion of young adults always susceptible to genital HSV-1 infection at initiation of sexual activity) and the oro-genital sexual practices. This feature is concerning in regards to neonatal herpes given that the risk of HSV vertical transmission is higher during primary infection than during reactivation [8] and that HSV-1 appears more readily transmissible to the neonate than HSV-2 [9]. It should be noted that genital HSV-1 infection does not prevent any risks of genital HSV-2 acquisition [9].

Worldwide, HSV-2 remains the main cause of genital herpes and is the major etiology of genital ulcer disease. In addition, HSV-2 infection has been proven to be an independent cofactor of HIV sexual transmission. In turn HIV1 infection increases the frequency of HSV-2 reactivations and mucosal shedding, as well as the quantity of shed viruses [7]. In severely immunocompromised HIV-1-infected patients and transplant patients, HSV infections frequently present as chronic, necrotic, extended, and confluent mucocutaneous ulcerations.

Most primary genital infections with HSV-1 and HSV2 are asymptomatic and all are followed by latent infection of neuronal cells in the dorsal root ganglia and only $10-25 \%$ of people with HSV-2 antibodies are aware of their genital herpes. However, a large proportion of seropositive patients present asymptomatic shedding episodes that contribute to the spread of these infections $[10,11]$.

\section{Importance of laboratory diagnosis or testing for genital herpes}

Genital herpetic infection is mainly diagnosed on clinical grounds, especially when the clinical picture is classical, with the presence of typical papular lesions progressing to vesicle and ulcerative lesions which finally crust, associated with local adenitis and in recurrent cases preceded by prodromal [12] (Figure 1). However, clinical diagnosis of genital herpes may be limited in accuracy. The clinical differentiation of genital HSV infection from other infectious (Treponemapallidum, Haemphilusducreyi) and noninfectious etiologies of genital ulceration is often difficult and laboratory confirmation of the infection should always be sought [13]. Besides classic vesicular lesions, HSV genital infection may be associated with other clinically atypical presentations. These include either unusual sites (extragenital regions: buttocks, thighs) or atypical morphological forms of genital disease (vulvar, penile or perianal fissures, localized recurrent erythema, recurrent radicular or lower back pain, cystitis, urethritis, vaginal discharge without overt genital lesions) [14,15]. Meningitis may be observed during phases of primary infection and reactivation and can also confuse the diagnosis of genital HSV infection [16]. Accordingly, exclusive reliance on clinical diagnosis could lead both to false positive and false negative diagnosis of the condition. Thus, a clinical diagnosis of genital herpes should be confirmed with laboratory tests [6,12,17-19].

The laboratory diagnosis of genital herpes is recommended in various situations:

- Confirmation of clinically suspected genital herpes.

- Variable presentation of genital herpes.

- Extra-genital complications of genital herpes [20].

- Differential diagnosis with other ulcerative STIs.

- Differential diagnosis with other genital ulcerative dermatoses (Crohn's disease, Behçet syndrome or fixed drug eruption).

Because HSV-1 has become a frequent etiology of genital herpes, species typing is also a cornerstone of genital herpes diagnosis. Whether genital herpes is caused by HSV-1 or HSV-2 influences prognosis and counseling. Even though up to $50 \%$ of first-episode cases of genital herpes are caused by HSV-1, recurrences and subclinical viral shedding are much less frequent for genital HSV-1 infection than genital HSV-2 infection. Thus, information regarding whether one is infected with HSV-1 or HSV-2 can prove useful in discussing risks for recurrence.

\section{Laboratory methods for direct herpes diagnosis Collection, transport and storage of clinical specimens for herpes diagnosis}

HSV-1 and HSV-2 can be recovered by swabbing mucocutaneous genital lesions and from previously involved 


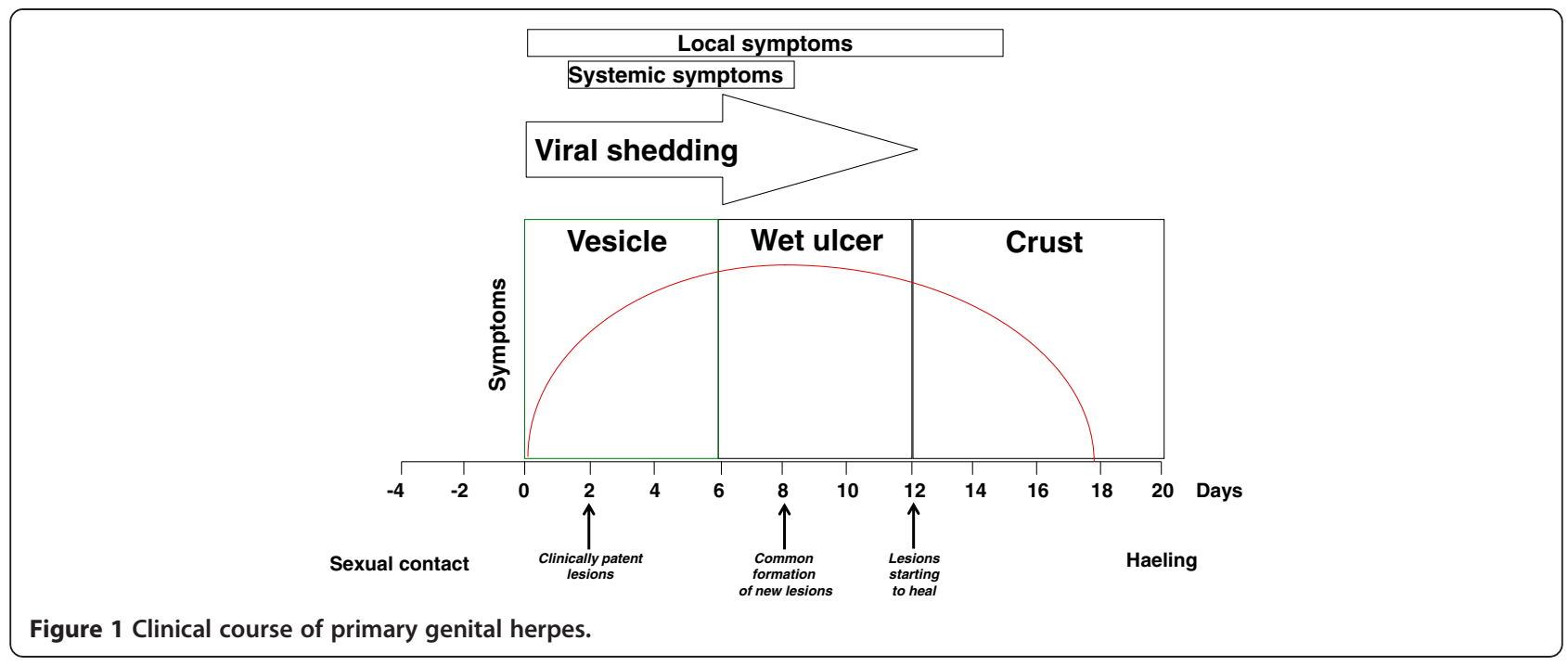

mucocutaneous sites in patients with asymptomatic infection.

For sample lesions collection, a small cotton, cottontipped, or Dacron swab on a wire shaft is used for viral culture as well as molecular biology. Nylon flocked swabs may be preferred since their perpendicular nylon fibers act like a soft brush to allow the improved collection and release from patient samples although no formal validation for herpes positive samples has been performed yet [21-23]. Calcium alginate swabs are toxic to HSV and therefore should not be used for virus isolation in cell culture [24].

For active lesions, collection of vesicular fluid or exudate from small vesicles is the method of choice. After sampling, the specimens for viral culture, antigen or detection of HSV DNA genome should be placed immediately into vials containing $1 \mathrm{ml}$ of appropriate viral transport medium, or an universal transport medium because HSV is highly sensitive to desiccation and $\mathrm{pH}$ inactivation. Specimen should also be transferred quickly to a diagnostic virology laboratory on ice $\left(+4^{\circ} \mathrm{C}\right)$ as the virus infectivity is heat labile. Molecular assays that do not require the virus infectiousness, tolerate less strict conditions for the sample transport. The use of transport medium may be not necessary as long as samples are stored at $+4^{\circ} \mathrm{C}$ and frozen until molecular analysis. It has been shown that inappropriate storage decreased the yield of HSV DNA [25].The level of viral nucleic acids collected from cervicovaginal lavages remain stable at $4^{\circ} \mathrm{C}$ for 24 hours but decreased significantly when they were stored at $20^{\circ} \mathrm{C}$ and $30^{\circ} \mathrm{C}$ [25].

For a diagnosis using cell culture, the use of alcohol or iodophors to cleanse the lesions before sampling the lesion should be avoided as it inactivates the virus.

The recommended sampling sites and type of sample and methods to be used for the diagnosis of genital herpes infection are presented in Table 1. The recommendations for sample transportation and storage using microscopy, culture and nucleic acid amplifications tests (NAAT) are presented in Table 2.

\section{Laboratory methods for direct herpes diagnosis}

Several tests with various specificities and sensitivities are used for the direct diagnosis of HSV infections (Table 3).

Viral culture with further herpes typing has been the cornerstone of HSV diagnosis over the past two decades and accepted as the gold standard for the laboratory diagnosis of HSV infections.

Viral antigen can be easily detected by direct immunofluorescence (IF) assay using fluorescein-labelled typespecific monoclonal antibodies on smears, or by enzyme immunoassay (EIA) on swabs. Although these assays lack sensitivity, they perform satisfactorily in symptomatic patients. Thus, these direct methods may offer a rapid diagnostic alternative in settings where laboratory facilities are limited, including resources-constrained countries.

Recently, HSV DNA detection based on nucleic acid amplification, and polymerase chain reaction (PCR) in particular, has emerged as an alternative method because it is about four times more sensitive, less dependent on collection and transport conditions, and faster than viral culture [26]. The 2010 CDC Sexually Transmitted Diseases Treatment Guidelines state that "PCR testing to diagnose herpes can be performed by clinical laboratories that have developed their own tests and have conducted a Clinical Laboratory Improvement Amendment (CLIA) verification study", and "cell culture and PCR are the preferred HSV tests for people who seek medical treatment for genital ulcers or other mucocutaneous lesions" (CDC, 2010). Since 2011 three molecular assays have been approved by the US Food and Drug Administration for the testing of genital 
Table 1 Recommendations for sample collection for the diagnosis of genital herpes infections, adapted from Domeika and colleagues [9]

\begin{tabular}{|c|c|}
\hline Collection site & Tools for sample collection \\
\hline \multirow{3}{*}{$\begin{array}{l}\text { Male skin or mucous } \\
\text { membrane lesions }\end{array}$} & - Sterile needles \\
\hline & $\begin{array}{l}\text { - Sterile cotton-tipped, Dacron or nylon flocke } \\
\text { swab on a wooden, plastic or aluminium sha }\end{array}$ \\
\hline & - Microscope slides \\
\hline Male urethra & $\begin{array}{l}\text { - Sterile cotton-wool, Dacron or nylon flocked } \\
\text { swab on a wooden, plastic or aluminium sha }\end{array}$ \\
\hline \multirow[t]{2}{*}{$\begin{array}{l}\text { Female skin or } \\
\text { mucous membrane } \\
\text { lesions }\end{array}$} & $\begin{array}{l}\text { - Gauze and cotton swabs, dacron or nylon } \\
\text { flocked swab on a wooden, plastic or } \\
\text { aluminium shaft }\end{array}$ \\
\hline & - Microscope slides \\
\hline \multirow[t]{2}{*}{ Female urethra } & $\begin{array}{l}\text { - Sterile gauze swab (to remove excess } \\
\text { discharge) }\end{array}$ \\
\hline & $\begin{array}{l}\text { - Sterile cotton-wool, Dacron or nylon flocked } \\
\text { swab on an aluminium shaft }\end{array}$ \\
\hline \multirow[t]{3}{*}{ Cervix } & - Vaginal speculum \\
\hline & - Sterile gauze swab \\
\hline & $\begin{array}{l}\text { - Sterile cotton-wool, Dacron or nylon flocked } \\
\text { swab on a wooden or plastic shaft }\end{array}$ \\
\hline
\end{tabular}

Vagina(of $\quad$ Sterile cotton-wool, Dacron or nylon flocked prepubertal girls) swab on an aluminium shaft

Urine $\quad$ Sterile container for urine

Conjunctiva

- Sterile cotton-wool, Dacron or nylon flocked swab on an aluminium shaft

- Kimura platinum conjunctival scraper

- Topical ophthalmic local anaesthetic

Rectum $^{\mathrm{a}}$

- Rectal speculum or proctoscope

- Sterile cotton-wool, Dacron or nylon flocked swab on a wooden or aluminium shaft

\section{Collection method}

- Unroof the vesicles with a sterile needle

- Collect the content of the vesicles with a sterile swab and:

o apply to a microscope slide (for immunofluorescence staining) or 0 introduce into transport media for viral culture or NAAT.

- Clean the external urethral opening region with a swab moistened in saline

- Draw back the prepuce to avoid contamination when sampling

- Insert a sterile swab carefully into the external urethral meatus (to a depth of $0.5-2 \mathrm{~cm}$ ) and collect urethral exudates for testing

- Similarly as for male skin or mucous membrane lesions

- Clean the introitus using a sterile gauze swab

- Carefully insert a sterile swab on an aluminium shaft into the urethra (to a depth of $0.5 \mathrm{~cm}$ ) to collect exudates for testing

- Insert the vaginal speculum, which may be moistened in advance with warm water and

- clean the cervical canal opening thoroughly with a sterile gauze swab

- Insert a cotton-wool or Dacron swab carefully into the cervical canal (to a depth of $2 \mathrm{~cm}$ ) and collect the material from lesions.

- Insert a sterile swab on an aluminium shaft carefully through the hymen into the vagina, and collect the material from the back wall of the vagina

- Ask the patient to collect the first 10-20 ml of voided urine (first catch)

- The patients should avoid urinating for least two hours before sampling

- purulent discharge must be removed before sampling with a sterile swab

- Move a swab over the conjunctiva of the inferior eyelid towards the interior angle of the eye (use a thin swab on an aluminium shaft for newborns)

- The Kimura scraper is used to sample the bases of lesions (either ulcers or the bases of burst vesicles). Before collecting the sample, the spatula is sterilised by heating in a flame and allowed to cool

- Rectal material is taken under direct vision, with the aid of a proctoscope or rectal speculum. Use of a blind technique results in considerable loss of sensitivity

- Insert a swab on a wooden or plastic shaft to a depth of $3 \mathrm{~cm}$ and collect the material from all rectal walls by circular motions for 10 seconds

- If faecal material is impacted, the swab should be discarded and the sampling procedure repeated.

${ }^{a}$ Material from the rectum is collected when the patient has had anal sexual contact, when he suffers from anorectal inflammation, or if perianal skin or anal folds are thickened.

NAAT: nucleic acid amplification test.

specimens (IsoAmp HSV Assay, BioHelix Corporation; MultiCode-RTx Herpes Simplex Virus 1 \& 2 Kit, EraGen Biosciences, Inc.; BD ProbeTec Herpes Simplex Viruses (HSV I \& 2) QX Amplified DNA Assays, BD Diagnostic Systems).
Based on our practice, when molecular testing is available, its use should be preferred over viral culture. Molecular testing will also confirm viral shedding whether or not lesions are present [27]. When no facilities are available to carry out cell culture or molecular assays, 


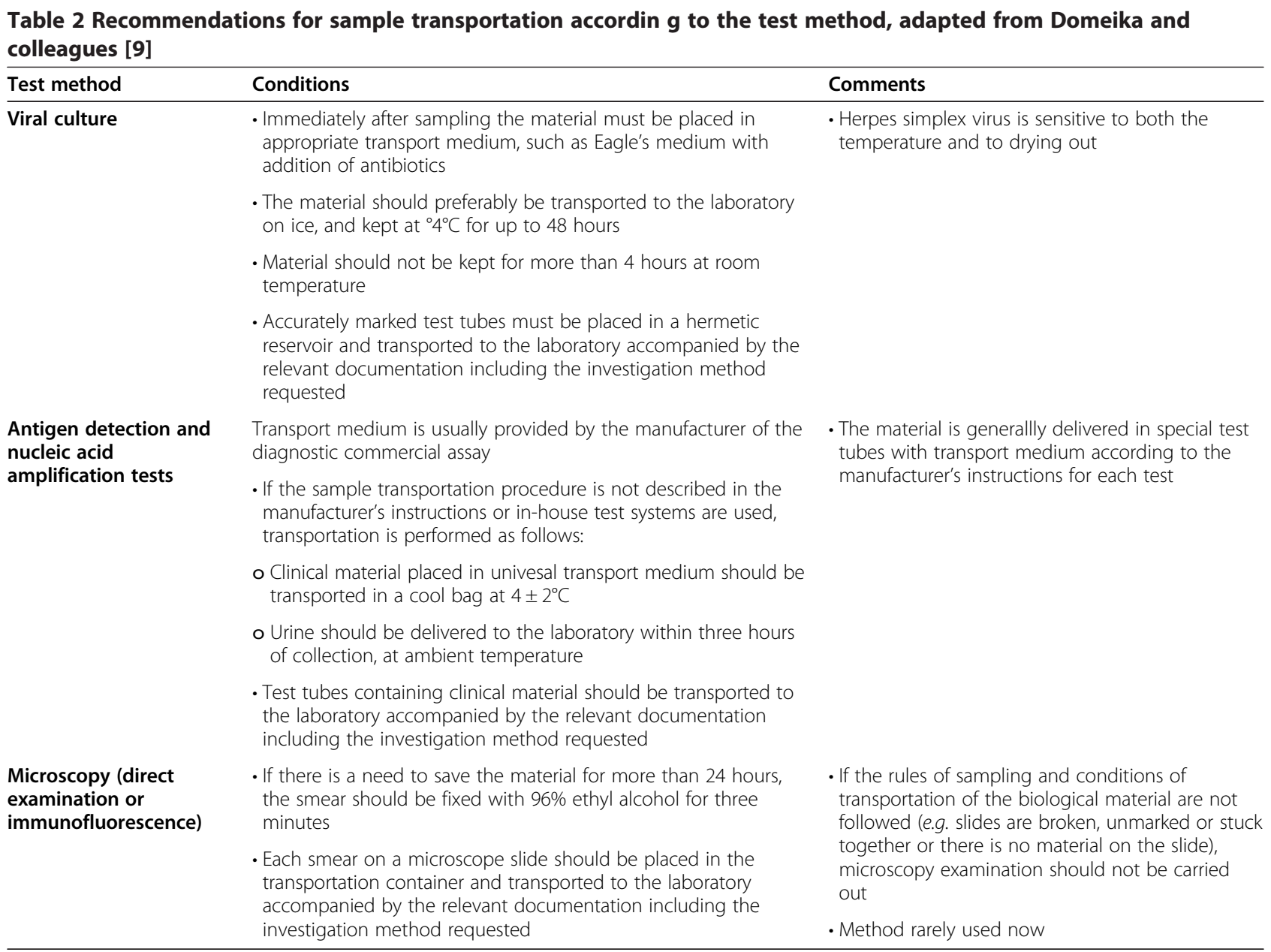

NAAT: nucleic acid amplification test.

antigen detection is useful and can provide a rapid diagnosis, mainly when mucocutaneous lesions are present.

The recommended sites and methods to be used in the direct diagnosis of genital herpes lesions are presented in Table 4.

\section{Virus isolation and typing in cell culture}

Several primary, diploid and continuous cell lines may be used for isolation of HSV from clinical specimens. Commonly used cells, sensitive to different viruses, include mainly primary human diploid fibroblasts, such as MRC-5 cells, and cell lines, such as Vero cells (monkey kidney), HEp-2 cells (laryngeal squamous cell carcinoma), baby hamster kidney and rabbit kidney cells [28]. The parallel inoculation of two different cell lines can minimize the effects of periodic variations in cell line sensitivity.

Culture cells are first allowed to grow into a confluent monolayer in a tissue culture tube flattened on one side. The cytopathic effect (CPE) caused by HSVusually develops 24-72 hours after inoculation, and is characterized by enlarged, refractile, and rounded cells. Focal necrosis of cells may occur and syncytia and multinucleated giant cells may be present. Within days, the monolayer may be destroyed. The incubation time required to observe the cytopathic effect of HSV depends on the concentration of the virus in the clinical specimen: samples with high titers of virus produce CPE in less than 48 hours, whereas samples with a low concentration produce CPE after 4-6 days. Cultures should be held for seven to 10 days. The highest isolation rates of HSV are likely if the clinical specimens are inoculated on the day they are taken. It is important to give attention to the conditions of transport and storage of clinical specimens. They must be stored at $+4^{\circ} \mathrm{C}$ during transport and maintained at this temperature for no longer than 48 hours. At ambient temperature, transport duration should be less than 4 hours. If a delay of more than 48 hours is expected between collection and culture, the specimens should be frozen at best at $-80^{\circ} \mathrm{C}$ for further inoculation. Virus titers are remarkably reduced in frozen and thawed samples, and freezing at $-20^{\circ} \mathrm{C}$ is not advised [25].

Confirmation of $\mathrm{HSV}$ in viral culture demonstrating cytopathic effect is recommended since other viruses may exhibit a cytopathic effect similar to that observed 
Table 3 Direct laboratory methods for HSV diagnosis

\begin{tabular}{|c|c|c|c|c|c|c|}
\hline Method & Principle & Sample & Sensitivity & Specificity & Advantages & Disadvantages \\
\hline \multirow{9}{*}{$\begin{array}{l}\text { Viral antigen } \\
\text { detection }\end{array}$} & \multirow{5}{*}{ Immunopreoxidase staining } & Swab & \multirow[t]{5}{*}{ Middle (80\%) } & \multirow[t]{5}{*}{ High (90\%) } & Reagent cost & Fresh vesicles \\
\hline & & Smears from lesions & & & Rapid $(<4$ hours & Suboptimal sensitivity \\
\hline & & \multirow{3}{*}{$\begin{array}{l}\text { Smear or vesicular } \\
\text { fluid of exudate from } \\
\text { base of vesicle }\end{array}$} & & & & \\
\hline & & & & & $\begin{array}{l}\text { Does no require } \\
\text { the integrity of the } \\
\text { specimen }\end{array}$ & \\
\hline & & & & & Typing possible & \\
\hline & \multirow[t]{2}{*}{ Capture ELISA } & Swab & \multirow{2}{*}{$\begin{array}{l}\text { High (Genital } \\
\text { ulcer: }>95 \%)\end{array}$} & \multirow[t]{2}{*}{ High (62-100\%) } & & Fresh vesicles \\
\hline & & $\begin{array}{l}\text { Vesicular fluid or } \\
\text { exudate from base of } \\
\text { vesicle }\end{array}$ & & & & No viral typing \\
\hline & \multirow[t]{2}{*}{ Rapid test device } & Swab & \multirow[t]{2}{*}{ Unknown } & \multirow[t]{2}{*}{ Unknown } & \multirow{2}{*}{$\begin{array}{l}\text { Point-of-care } \\
\text { testing }\end{array}$} & \multirow[t]{2}{*}{ Not yet evaluated } \\
\hline & & $\begin{array}{l}\text { Vesicular fluid or } \\
\text { exudate from base of } \\
\text { vesicle }\end{array}$ & & & & \\
\hline \multirow[t]{11}{*}{ Virus culture } & \multirow[t]{11}{*}{ HSV isolation susceptible cells } & Swab & \multirow{2}{*}{$\begin{array}{l}\text { Low to high } \\
\text { depending of the } \\
\text { clinical context }\end{array}$} & \multirow[t]{11}{*}{ High ( $\approx 100 \%)$} & \multirow{2}{*}{$\begin{array}{l}\text { Allows virus } \\
\text { isolation }\end{array}$} & Less sensitive than PCR \\
\hline & & \multirow[t]{2}{*}{ Skin lesions } & & & & \multirow{2}{*}{$\begin{array}{l}\text { Sample storage and transport conditions } \\
\text { influence sensitivity }\end{array}$} \\
\hline & & & Vesicular content: & & \multirow{4}{*}{$\begin{array}{l}\text { Classically, "gold } \\
\text { standard" method } \\
\text { Currently, } \\
\text { "preferred" test } \\
\text { (CDC 2010) }\end{array}$} & \\
\hline & & \multirow{3}{*}{$\begin{array}{l}\text { Vesicular fluid or } \\
\text { exudate from base of } \\
\text { vesicle }\end{array}$} & $>90 \%$ & & & \multirow{2}{*}{$\begin{array}{l}(\rightarrow \text { Rapid transport, cooled, protected from } \\
\text { light in virus transport medium) }\end{array}$} \\
\hline & & & Ulcer : 95\% & & & \\
\hline & & & Swab : 70\%-80\% & & & Labor-intensive \\
\hline & & \multirow{3}{*}{$\begin{array}{l}\text { Mucosal sample } \\
\text { without lesions } \\
\text { Biopsies }\end{array}$} & \multirow[t]{3}{*}{$\begin{array}{l}\text { Mucosa without } \\
\text { lesion: } 30 \%\end{array}$} & & $\begin{array}{l}\text { Simplicity of } \\
\text { sampling }\end{array}$ & Expensive \\
\hline & & & & & Virus typing & Specialized laboratories \\
\hline & & & & & Resistance & Results in $2 / 7$ days \\
\hline & & $\begin{array}{l}\text { Conjunctival/corneal } \\
\text { smear }\end{array}$ & & & Phenotype testing* & Arrangement with laboratory necessary \\
\hline & & Neonates & & & & \\
\hline \multirow{6}{*}{$\begin{array}{l}\text { Molecular } \\
\text { biology }\end{array}$} & \multirow{6}{*}{$\begin{array}{l}\text { HSV DNA detection and/or quantitation by } \\
\text { NAAT, including in-house classical PCR, real- } \\
\text { time PCR and commercial assays }\end{array}$} & Swab & Highest & High. & High sensitivity. & Only in specialized laboratories \\
\hline & & Skin lesions & $(98 \%)$ & $(\approx 100 \%)$ & & \\
\hline & & $\begin{array}{l}\text { Vesicular fluid or } \\
\text { exudate from base of } \\
\text { vesicle }\end{array}$ & & \multirow{4}{*}{$\begin{array}{l}\text { Containment of } \\
\text { potential cross- } \\
\text { contamination } \\
\text { important }\end{array}$} & $\begin{array}{l}\text { Currently, } \\
\text { "preferred" test } \\
\text { (CDC 2010) }\end{array}$ & Not standardized \\
\hline & & \multirow{3}{*}{$\begin{array}{l}\text { Mucosal sample } \\
\text { without lesions }\end{array}$} & & & \multirow{3}{*}{$\begin{array}{l}\text { Allows virus } \\
\text { detection and } \\
\text { typing in the same } \\
\text { test }\end{array}$} & Not validated for all samples \\
\hline & & & & & & Risk of contamination (PCR) \\
\hline & & & & & & May be relatively expensive (real-time PCR) \\
\hline
\end{tabular}




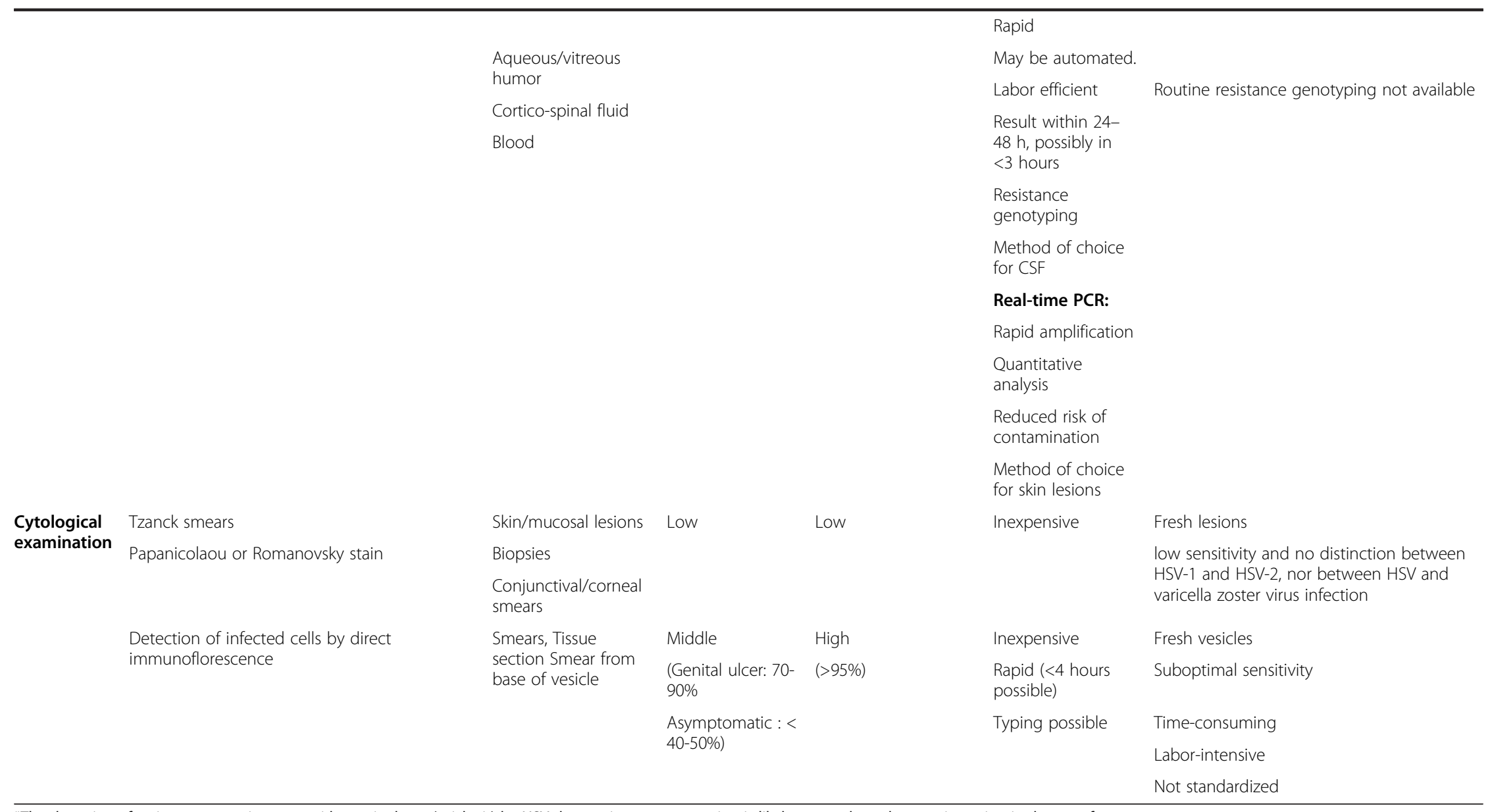


Table 4 Recommended sampling sites, type of sample and preferred diagnostic methods for genital herpes, adapted from Domeika and colleagues [9]

\begin{tabular}{ll}
\hline Sampling site or type of sample & Preferred diagnostic method \\
\hline $\begin{array}{l}\text { Vesicule on skin and mucous } \\
\text { membranes Ulcer }\end{array}$ & NAAT; viral culture; \\
antigen detection* & Urethra (male) \\
Cervix/urethra (female) & NAAT; antigen detection* antigen detection* \\
Urine (men and women) & NAAT; viral culture \\
Vulva/vagina (prepubertal girls) & NAAT \\
Vagina (women after hysterectomy) &
\end{tabular}

*Viral antigen detection by direct immunofluorescence on smears or enzyme immunoassay on swabs may offer a rapid diagnostic alternative in settings where culture or molecular diagnosis are not available. NAAT: nucleic acid amplification test.

in herpes culture, and allows viral typing. Typing of HSV using cell culture can be performed directly on infected cell cultures using fluorescein-labelled typespecific monoclonal antibodies by direct immunofluorescence which constitutes the most practicable procedure, or, eventually, by testing the cell supernatant by molecular assays [28].

As standard virus isolation in tissue culture may be slow, in particular for samples with low viral titers, many laboratories now use centrifugation-enhanced (shell vial) culture methods combined with staining with a type-specific monoclonal antibody before the CPE onset to reduce viral isolation times $[29,30]$. Shell vial culture can reduce viral isolation time from one to seven days to just 16-48 hours.

Genetically engineered cell lines have been developed to allow an early detection of HSV-1 and HSV-2 after an overnight incubation. The Enzyme Linked Virus Inducible System (ELVIS, Diagnostic Hybrids, Inc, USA) utilizes genetically engineered cell lines transfected with an inducible HSV promoter gene linked to anEscherichia coliLacZ reporter gene [31]. Replication of HSV in these cells induces galactosidase production, and infected cells stain blue when overlaid with an appropriate substrate [32]. Typing can then be performed using type-specific antisera on any monolayers showing blue cells.

Diagnosis of HSV infection with tissue culture has low sensitivity because HSV is isolated from lesions in about $80 \%$ of primary infections but in only $25-50 \%$ of recurrent lesions, and in even fewer people whose lesions have begun to heal. Thus, fluid collected from intact blisters (vesicular or pustular lesions) will grow out in culture more than $90 \%$ of the time. By the time the lesions have crusted over, only about $25 \%$ of cultures will be positive. Failure to detect HSV by culture does not indicate an absence of HSV infection [26].

\section{Antigen detection}

Viral antigen can be easily detected by direct or indirect immunofluorescence (IF) assay using fluorescein-labelled type-specific monoclonal antibodies on smears, or by enzyme immunoassay (EIA) on swabs. For detecting HSV in lesions, the sensitivity of antigen detection tests may be the same as that of culture assay but is lower than nucleic acid amplification test sensibility [4]. As indirect IF assay and EIA perform satisfactorily in symptomatic patients, these direct methods may offer a rapid diagnostic alternative in settings where laboratory facilities are limited and where specimen handling and transportation conditions could inactivate the virus. This is true for remote locations where prolonged specimen transport time under inappropriate conditions may occur before delivery to the microbiology laboratory.

For immunofluorescent assays, the slide should be prepared by the laboratory using a cytospin method to guarantee the quality of the slide reading. Under a fluorescence microscope, infected cells will be recognized by the presence of a characteristic pattern of apple-green fluorescence in the nucleus and cytoplasm of the basal and parabasal cells.

Several EIA assays are commercially available but few have been FDA approved.

\section{Virus detection and quantification by molecular biology}

Molecular biology has emerged for the last ten years as an attractive potent method to detect and possibly quantify HSV DNA. Most of NAATs are based on the PCR but some use a different approach for the amplification of nucleic acid.

Several procedures have been proposed to detect and/ or quantify HSV genomes in clinical samples, including in-house competitive PCR [33], PCR detection followed by DNA enzyme immunoassay hybridization [34], realtime PCR assay $[4,5,35,36]$, and various commercially available kits. The majority of in-house or commercial PCR targeting the HSV genome are currently based on real-time PCR which allows both the detection and the quantification of HSV DNA in clinical samples. Compared with traditional PCR (also called end-point PCR) revealed either with agarose gel migration or enzyme hybridization assay, real-time PCR is faster, less laborintensive with minimal technical hands-on time and a lower risk of molecular contamination. Primers from HSV DNA sequence common to both HSV-1 and HSV2 [HSV DNA polymerase, HSV thymidine kinase or glycoprotein B] may identify HSV DNA. In some assays, a melting curve at the end of real-time PCR helps discern HSV-1 from HSV-2 $[4,5,36]$. Primers and probes from HSV DNA sequence specific to HSV-1 or HSV-2, including, gB, gD, or gG genes, allows also the amplification of one specific herpes type [35,37-40]. In each 
experiment positive and negative controls should be run. In addition, the use of internal controls spiked before nucleic acid extraction is recommended to detect the presence of any amplification inhibitors that could lead to false-negative results.

PCR assays or other NAATs are the most sensitive test currently available to detect HSV in clinical samples. The detection rates of the PCR assays were shown to be $11-71 \%$ superior to virus culture $[26,41-44]$. Furthermore, NAAT allows the best detection of asymptomatic shedding of genital herpes beside symptomatic infections [26]. However, failure to detect HSV by PCR does not indicate an absence of HSV infection, because viral shedding is intermittent [11].

Three NAATs have been approved by the US Food and Drug Administration for the testing of genital specimens (IsoAmp HSV Assay, BioHelix Corporation; MultiCodeRTx Herpes Simplex Virus 1 \& 2 Kit, EraGen Biosciences, Inc.; BD ProbeTec Herpes Simplex Viruses (HSV I \& 2) QX Amplified DNA Assays, BD Diagnostic Systems).

The IsoAmp HSV Assay uses isothermal helicasedependent amplification in combination with a disposable, hermetically-sealed, vertical-flow strip identification, limiting the technical hands-on time and risk of cross-contamination. Once DNA is purified from the sample, the assay has a total test-to-result time of about 1.5 hours. The diagnostic sensitivity and specificity are comparable to end-point PCR and are superior to culture-based methods. The performances have not been compared to real-time PCR assays. The assay is FDA approved for the detection of herpes simplex viruses (HSV) in genital and oral lesion specimens. The assay does not provide specific typing information to differentiate HSV-1 from HSV-2. The assay is not intended to be used for prenatal screening [45].

The MultiCode-RTx Herpes Simplex Virus 1 \& 2 Kit utilizes real-time PCR molecular detection. MultiCode-RTx technology site-specifically incorporates an isoG triphosphate, covalently attached to a DABCYL quencher, opposite an isoC base that is adjacent to a $5^{\prime}$ fluorescent label in one of the primers. PCR amplification is performed using the Roche LightCycler 1.2 instrument. Incorporation of the quencher-labeled nucleotide causes a decrease in assay fluorescence when the product is a double-stranded DNA molecule. The PCR primers target a type-specific DNA sequence within the herpes simplex virus glycoprotein B gene. The MultiCode-RTx Herpes Simplex Virus 1 \& 2 Kit is indicated for use in the detection and typing of HSV-1 or HSV-2 in vaginal lesion swab specimens from symptomatic female patients. The assay provided similar sensitivity and specificity compare to two other commercial real-time PCR assays on CSF samples [46].

The BD ProbeTec Herpes Simplex Viruses (HSV-1 \& -2) QX Amplified DNA Assay is a fully automated assay for
HSV-1 and HSV-2 molecular detection and typing on the BD Viper ${ }^{\text {Tim }}$ System. The PCR primers target a type-specific DNA sequence within the HSV glycoprotein G gene. It is approved for the detection and differentiation of HSV-1 and HSV-2 in anogenital samples. It has been compared to HSV culture and a laboratory-developed real-time PCR assay with 508 clinical specimens. The sensitivity of HSV-2 detection ranged from $98.4-100 \%$ depending on the analytical approach, while the specificity ranged from $80.6 \%$, compared to the less sensitive culture method, to $97.0 \%$, compared to PCR. For HSV-1, the sensitivity and specificity ranges were $96.7-100 \%$ and $95.1-99.4 \%$, respectively [47].

\section{Indirect serological diagnosis of herpetic infections}

Detection of HSV-specific IgG antibodies can be done sensitively by several immunological methods. Serologic diagnosis of HSV infections and HSV type-specific antibody testing are summarized in Table 5, and commercially available assays approved by the Food and Drug Administration (FDA, United States) in Table 6. Accurate type-specific HSV serologic assays are based on the detection of HSVspecific gG1 (HSV-1) and gG2 (HSV-2) antibodies using native, purified or recombinant gG1 or gG2 as antigens. Serological assays based on antigen preparations from whole virus or from crude infected-cell protein mixtures detect predominantly type-common antibodies, may have low sensitivity in detecting HSV-2 antibodies in HSV-1seropositive patients, or may incorrectly type antibodies in patients with only HSV-1 or HSV-2 infection. Some commercial assays described as "type-specific" are actually based on relative reactivity of serum antibodies to crude preparations of HSV-1 versus HSV-2 antigens. The accuracy of such tests for HSV-2 antibody detection is low compared with glycoprotein G-based tests, and their use is not recommended [48].

Type-specific IgG antibodies are negative in early presentations of herpes disease, and become detectable two weeks to three months after the onset of symptoms and persist indefinitely. Thus, immediately after infection there is a 'window' in which testing for antibodies will give a negative result. Consequently, primary HSV infections can be documented by using any serologic methods to show seroconversion with paired sera. HSV IgM testing substantially increased the ability to detect early infection in patients who lack detectable IgG, but may be negative during primary disease. IgM testing can also be positive during reactivation of disease and cannot be used to distinguish primary from recurrent infection. Because of these limitations, HSV IgM testing has limited availability in routine diagnostic settings and cannot be recommended in routine clinical practice.

Gold standard noncommercial tests for HSV-2 include the immunodot enzyme assay (developed at Emory University, Atlanta, Georgia, United States), the Western blot test 
Table 5 Indirect serological assays for HSV diagnosis

\begin{tabular}{|c|c|c|c|c|c|c|}
\hline Method & Principle & Sample & Sensitivity & Specificity & Advantages & Disadvantages \\
\hline \multirow[t]{5}{*}{ Western blot } & \multirow[t]{2}{*}{ Western blot HSV-1 } & \multirow[t]{5}{*}{ Serum } & \multirow[t]{5}{*}{$\approx 100 \%$} & \multirow[t]{5}{*}{$\approx 100 \%$} & Reference ("gold standard") test proposed by University of Washington (USA) & $\begin{array}{l}\text { Not commercially } \\
\text { available }\end{array}$ \\
\hline & & & & & {$[U W-W B]$} & Expensive \\
\hline & \multirow[t]{3}{*}{ Western blot HSV-2 } & & & & Specific of HSV-1 and HSV-2 & \multirow[t]{3}{*}{$2-3$ days for results } \\
\hline & & & & & Detect early sero-conversion to HSV-2 in patient with prior HSV-1 infection & \\
\hline & & & & & Earliest sero-conversion : 13 days & \\
\hline \multirow{2}{*}{$\begin{array}{l}\text { Enzyme } \\
\text { immune-assay }\end{array}$} & \multirow{2}{*}{$\begin{array}{l}\text { Monoclonal } \\
\text { antibody-blocking EIA }\end{array}$} & \multirow{2}{*}{ Serum' } & \multirow{2}{*}{$\begin{array}{l}\approx 100 \% \\
\text { (African } \\
\text { sera : 98\%) }\end{array}$} & \multirow{2}{*}{$\begin{array}{l}\approx 100 \% \\
\text { (African } \\
\text { sera : 97\%) }\end{array}$} & Reference ("gold standard") test proposed by the Central Public Health Laboratory in & \multirow{2}{*}{$\begin{array}{l}\text { Not commercially } \\
\text { available }\end{array}$} \\
\hline & & & & & the Unitea kingaom; y8\% concoraance With WVU-WVB & \\
\hline \multirow[t]{2}{*}{$\begin{array}{l}\text { Enzyme } \\
\text { immune-assay }\end{array}$} & \multirow[t]{2}{*}{ ELISA } & \multirow[t]{2}{*}{ Serum } & \multirow[t]{2}{*}{$93-98 \%$} & \multirow[t]{2}{*}{$93-99 \%$} & Commercially available & $\begin{array}{l}\text { May lack of sensitivity } \\
\text { and specificity }\end{array}$ \\
\hline & & & & & Distinguish between HSV-1 and HSV-2 & $\begin{array}{l}\text { Lack of specific on } \\
\text { African sera }\end{array}$ \\
\hline \multirow[t]{4}{*}{$\begin{array}{l}\text { Point of care } \\
\text { tests }\end{array}$} & \multirow[t]{4}{*}{ Immuno-filtration } & \multirow[t]{4}{*}{$\begin{array}{l}\text { Serum } \\
\text { Capillaryblood }\end{array}$} & \multirow[t]{4}{*}{$96 \%$} & \multirow[t]{4}{*}{$87-98 \%$} & Less expensive than Western blot & $\begin{array}{l}\text { Commercially available } \\
\text { only for HSV-2 }\end{array}$ \\
\hline & & & & & Accurate results rapidly (6 min.) & Expensive \\
\hline & & & & & Easily to carry out & $\begin{array}{l}\text { Not for large volume } \\
\text { screening }\end{array}$ \\
\hline & & & & & $\begin{array}{l}\text { Detects seroconversion within } 4 \text { weeks of presentation of } 80 \% \text { of patients with HSV-2 } \\
\text { episodes }\end{array}$ & $\begin{array}{l}\text { Complexity nonwaived } \\
\text { (moderate) }\end{array}$ \\
\hline
\end{tabular}

UW-WB: Western blot test developed at the University of Washington.
U. 
Table 6 Commercially available serological assays for HSV diagnosis approved by the Food and Drug Administration (US) (FDA, 2013)

\begin{tabular}{|c|c|c|c|c|c|c|c|}
\hline \multirow[b]{2}{*}{ Assay } & \multirow[b]{2}{*}{ Manufacturer } & \multirow[b]{2}{*}{ Format } & \multirow[b]{2}{*}{ Collection method } & \multicolumn{2}{|c|}{ HSV-1 } & \multicolumn{2}{|c|}{ HSV-2 } \\
\hline & & & & Sensitivity & Specificity & Sensitivity & Specificity \\
\hline Biokit HSV-2 Rapid Test & Biokit & Point of care & $\begin{array}{l}\text { Heparinized capillary } \\
\text { whole blood, serum }\end{array}$ & NA & NA & $93 \%-96 \%$ & $95 \%-98 \%$ \\
\hline HerpeSelect HSV-1 and HSV-2 Immunoblot & Focus Diagnostics & $\begin{array}{l}\text { Western blot with } \\
\text { recombinant proteins }\end{array}$ & Serum & $99.3 \%$ & $95.1 \%$ & $97.3 \%$ & $93.7 \%$ \\
\hline HerpeSelect HSV-1 ELISA, HerpeSelect HSV-2 ELISA & Focus Diagnostics & ELISA & Serum & $91.2 \%-96 \%$ & 92. $3 \%-95.2 \%$ & $96.1 \%-100 \%$ & $97.0 \%-96.1 \%$ \\
\hline $\begin{array}{l}\text { CaptiaHsv } 1 \text { lgG Type Specific Elisa Kit\&CaptiaHsv } \\
2 \text { lgG Type Specific Elisa Kit }\end{array}$ & Trinity Biotech & ELISA & Serum & $87.9 \%-87.7 \%$ & $100 \%-98.2 \%$ & $96.7 \%-100 \%$ & $90.3 \%-91.5 \%$ \\
\hline Liaison HSV-1 \& Liaison HSV-2 Type SpecificlgGAssay & Diasorin & ELISA & Serum & $96.9 \%-98.7 \%$ & $91.3 \%-96.8 \%$ & $98.1 \%-94.8 \%$ & $98.0 \%-97.3 \%$ \\
\hline $\begin{array}{l}\text { Zeus ELISA HSV GG-2 IgG Test System \& Zeus ELISA } \\
\text { HSV GG-1 IgG Test System }\end{array}$ & Zeus Scientific & ELISA & Serum & $96.8 \%$ & $97.1 \%$ & $98.8 \%$ & $100 \%$ \\
\hline BioPlex HSV-1 \& HSV-2 IgG panel & Biorad & Luminex & $\begin{array}{l}\text { Serum, lithium heparini } \\
\text { plasma, EDTA plasma }\end{array}$ & $100 \%-100 \%$ & 98. $3 \%-97.4 \%$ & $99.4 \%-100 \%$ & $100 \%-100 \%$ \\
\hline Elecsys HSV-1 IgG and HSV-2 IgG assays & Roche Diagnostics & Chemiluminescence & $\begin{array}{l}\text { Serum, lithium heparin } \\
\text { plasma, EDTA plasma }\end{array}$ & $94.2 \%-91.0 \%$ & 90. $3 \%-95.7 \%$ & $93.6 \%-97.8 \%$ & $98.7 \%-98.7 \%$ \\
\hline
\end{tabular}

NA: Not Applicable. 
(developed at the University of Washington (UW-WB)), and the monoclonal antibody-blocking enzyme immunoassay (developed by the Central Public Health Laboratory, London, United Kingdom) [49,50]. These tests are used in their respective specialized reference laboratories but are not replicable in many settings, thereby limiting their suitability for large-scale epidemiologic studies. The UW-WB test has been used as a gold standard in several studies, including the evaluation of commercial serological assays required for clearance by the FDA, and in the evaluation of the performance of other gold standard tests. Despite its excellent performance, Western blot remains primarily a research tool. At present, Western blot is not FDA approved, and requires a high level of technical ability, time, and expense to perform.

Type-specific HSV glycoprotein G (gG)-based ELISA became commercially available in 1999 . The sensitivities of these gG type-specific tests for the detection of HSV2 antibody vary from $80-98 \%$, and false-negative results might be more frequent at early stages of infection [51]. The specificities of these assays are $\geq 96 \%$. The tests approved for use in the USA have sensitivity of $97-100 \%$ and specificity of 94-98\%, when measured in comparison with the Western blot. False-positive results can occur, especially in patients with a low likelihood of HSV infection. Repeat or confirmatory testing might be indicated in some settings, especially if recent acquisition of genital herpes is suspected [51]. Some HSV-2 strains have been identified with mutations or deletions in gG2-gene leading either to the lack of gG-2 expression or the production of truncated forms [52,53]. Infections with such variants caused genital lesions similar to wild HSV-2 infection but immune response to gG-2 were either reduced or absent $[52,53]$. Negative detection of type-specific HSV-2 antibodies does not eliminate the rare possibility of a HSV-2 infection. HSV-2
DNA detection or HSV-2 isolation in cell culture along with a negative serology beyond the primary infection suggests an infection with a gG-2 deficient HSV-2 strain.

HerpeSelect $^{\circ}$ ELISA tests (HerpeSelect ${ }^{\circ} 1$ ELISA IgG Herpes Simplex Virus-1 (HSV-1) ELISA IgG; HerpeSelect $^{\circ} 2$ ELISA IgG Herpes Simplex Virus-2 (HSV-2) ELISA IgG,Focus Technologies, Inc., Cypress, CA [formerly MRL Diagnostics]) are FDA approved, widely available and have been extensively studied [51,54-57].

Point-of-care rapid tests can also provide results for HSV-2 antibodies from capillary blood or serum during a clinic visit. These immunoassays are designed to use capillary blood from a finger stick (or serum) and typically employ lateral flow of serum through a membrane containing a dot of gG1 or gG2 antigen. When serum is applied to the kit, a visual color change develops (pink dot) if herpes antibodies are present. Despite a reported inter-operative variability of $5-10 \%$ in test interpretation, these point-of-care tests perform relatively well with sensitivities $\geq 91 \%$ and specificities $\geq 94 \%$ [48]. The major benefit of point-of-care assays is that they give results rapidly (potentially while the patient is still in the clinical site,) allowing for more timely patient education and counseling. The major drawback of these tests is their cost relative to herpes ELISA-based systems.

If genital lesions are present, type-specific serology and direct virus testing can help to establish if the episode is a new HSV infection or reactivation (Table 7).

Type-specific HSV antibodies can take from 2 weeks to 3 months to develop. Thus, in a person with newly acquired herpes the initial absence of IgG antibodies specific for gG and subsequent development of such antibodies after 12 weeks confirms new HSV infection. The distinction between newly acquired HSV and reactivated HSV is helpful for epidemiological studies, and is sometimes helpful clinically for management of

Table 7 Virological and serological approach to HSV-2 diagnosis in the presence and absence of genital lesions, adapted from Gupta and colleagues [5]

\begin{tabular}{|c|c|c|c|c|}
\hline & $\begin{array}{l}\text { HSV-2 detection } \\
\text { by direct method }\end{array}$ & $\begin{array}{l}\text { HSV-1- } \\
\text { specific lgG }\end{array}$ & $\begin{array}{l}\text { HSV-2- } \\
\text { specific IgG }\end{array}$ & Interpretation \\
\hline \multirow{3}{*}{$\begin{array}{l}\text { First assessment of genital } \\
\text { lesions }\end{array}$} & \multirow[t]{2}{*}{ Positive } & \multirow{2}{*}{$\begin{array}{l}\text { Positive or } \\
\text { negative }\end{array}$} & \multirow[t]{2}{*}{ Negative } & Acute HSV-2 infection \\
\hline & & & & Repeat HSV-2-specific serology within 15-30 days \\
\hline & Positive & $\begin{array}{l}\text { Positive or } \\
\text { negative }\end{array}$ & Positive & $\begin{array}{l}\text { Recurrent HSV-2 infection with HSV-2 infection acquired at least } \\
6 \text { weeks ago }\end{array}$ \\
\hline \multirow[t]{3}{*}{ No lesions } & NA & Negative & Negative & $\begin{array}{l}\text { Patients at risk for acquiring orolabial or genital HSV-1 infection and/ } \\
\text { or HSV-2 infections }\end{array}$ \\
\hline & NA & Positive & Negative & Patients at risk for acquiring orolabial or genital HSV-2 infections \\
\hline & NA & Positive & Positive & HSV-1 and HSV-2 past-infections \\
\hline \multirow[t]{2}{*}{ Recurrentgenitallesions } & Positive & $\begin{array}{l}\text { Positive or } \\
\text { negative }\end{array}$ & Positive & Recurrent HSV-2 infection \\
\hline & Negative & Negative & Positive & $\begin{array}{l}\text { Possible recurrent HSV-2 infection Other potential causes of genital } \\
\text { ulcerative disease should be considered }\end{array}$ \\
\hline
\end{tabular}


psychosocial issues, because it can help clarify the source of infection.

Because nearly all HSV-2 infections are sexually acquired, the presence of type-specific HSV-2 antibody implies anogenital infection; thus, education and counseling appropriate for people with genital herpes should be provided. The presence of HSV-1 antibody alone is more difficult to interpret. The majority of people with HSV-1 antibody have oral HSV infection acquired during childhood, which might be asymptomatic. However, acquisition of genital HSV-1 appears to be increasing, and genital HSV-1 also might be asymptomatic.

Taken together, type-specific HSV serological assays might be useful in the following situations (Table 8):

- Recurrent genital symptoms or atypical symptoms with negative HSV cultures;

- Clinical diagnosis of genital herpes without laboratory confirmation;

- Partner with genital herpes.

In addition, HSV serologic testing should be included in a comprehensive evaluation for STIs among people with multiple sex partners, HIV infection, and men who have sex with men who are at increased risk for HIV acquisition. Screening for HSV-1 or HSV-2 in the general population is not recommended, due to concerns that HSV-2 diagnosis provides no benefit and could lead to psychosocial sequelae (Table 8 ).

However some data suggest that most people are interested in HSV-2 testing, which may result in safer sex practice. A review examined studies that measured the short and long-term psychosocial effects resulting from serological diagnosis of HSV-2 in persons without recognized symptoms of genital herpes infection [58]. Overall HSV-2 serological testing did not result in long-term psychosocial harm in most people. Recently a study conducted in pregnant women showed that serotesting sexual partners of pregnant women for HSV reduced the frequency of unprotected genital sex acts in pregnant women at known risk of HSV-2 acquisition compare to HSV-2-seronegative women with partners who were negative or not tested [59].

\section{Therapeutic monitoring: drug resistance testing}

Long-term prophylaxis and treatment with antiviral drugs targeting the viral DNA polymerase (DNA pol) can result in the development of resistance [60]. The prevalence of acyclovir-resistant HSV is about $1 \%$ in immunocompetent individuals and increases in immuncompromised patients, 5\% in HIV-seropositive individuals and $30 \%$ in hematopoietic stem cell recipients $[61,62]$. Antiviral drugs such as acyclovir or valacyclovir inhibit the viral DNA pol in triphosphorylated form, the
Table 8 Indications of type specific serology

\begin{tabular}{ll}
\hline Context & Indication and interpretation \\
\hline Asymptomatic patients & Not routinely recommended \\
Confirmation of clinical diagnosis & HSV-2 antibodies are supportive of \\
& a diagnosis of genital herpes. \\
History of recurrent or atypical & HSV-1 antibodies do not \\
genital disease with direct virus & differentiate between genital and \\
detection negative & oropharyngeal infection.
\end{tabular}

Counseling of HSV-2 lgG-negative, HSV-1 lgG-positive patients should take into account that HSV-1 is an uncommon cause of recurrent genital disease.

First-episode genital herpes

Differentiation between primary and established infection guides counseling and management.

At the onset of symptoms, the absence of HSV IgG against the virus type detected in the genital lesion is consistent with a primary infection.

Seroconversion should be demonstrated at follow-up.

Partner with genital herpes

Knowledge of infection status can guide patient education and counseling if the partnership is discordant

Pregnant women

Not routinely recommended.

HSV-1 and/or HSV-2 seronegative women should be counseled about strategies to prevent a new infection with either virus type during pregnancy.

HIV infected patients

Not routinely recommended.

Although HSV-2 seropositivity increases the risk of HIV transmission and frequent HSV recurrences augment HIV replication, there is limited evidence to inform the management of HSV-2 co-infection in HIV-infected patients without symptoms of genital herpes.

Limited data suggest an increased risk of perinatal HIV transmission among HSV-2 seropositive HIVinfected women. As the evidence is not consistent, testing of HIVpositive pregnant women is not routinely recommended.

first phosphorylation step ensured by the viral thymidine kinase (TK) and the subsequent steps by host cell kinases. Therefore mutations in both DNA pol and TK may confer resistance to antiviral drugs (Table 9). Because a functional TK may be dispensable but not the DNA pol for HSV replication, there is a higher probability of inducing a viable acyclovir-resistant virus by a mutation in the UL23 gene coding for TK than by a mutation in the UL30 gene coding for DNA pol. 
Table 9 Molecular changes associated with anti-herpetic drugs resistance in thymidine kinase (TK) and DNA polymerase (DNA pol) genes of Herpes simplex virus type 1 (HSV-1) and type 2 (HSV-2) according to amino acid mutations, stop codon and nucleotide insertion or deletion reported in the literature [29-34]

\begin{tabular}{|c|c|c|c|c|c|}
\hline Gene & Drug & Aminoacidmutations $^{a}$ & Stop $_{\text {codon }}{ }^{a}$ & Nucleotide insertion/deletion $^{\mathbf{b}}$ & Association of mutations $\mathrm{s}^{\mathrm{a}}$ \\
\hline HSV-1 TK & ACV & $\begin{array}{l}\text { R51W, Y53P/D/H, D55N, G56SN, P57H, K62N, H58R/L, } \\
\text { G59R/Y/W, G61V, K62N, T63A/I/S, T64A/S, T65N, E83K, } \\
\text { P84S, V87H, T103P, Q104H, H105P, Q125E/L, M128A/F, } \\
\text { G129D, G144N/R, A156V, D162A, R163H/C, A167V, } \\
\text { A168T, L170P, Y172C/F, P173L/R, A174P, A175V, R176Q, } \\
\text { L178R, S181N, Q185R, V187M, A189V, G200C/D, T201P, } \\
\text { G206R, L208H, R216C/H/S, R220C/H, R222C/H, L227F, } \\
\text { Y239S, T245M/P, T287M, L297S, L315S, C336Y, L364P }\end{array}$ & $\begin{array}{l}\text { Y53, S74, E95, T103, Q104, } \\
\text { R176, Q250, Q261, R281, } \\
\text { L341, C336, Q342, L364, } \\
\text { A375 }\end{array}$ & $\begin{array}{l}133-136,153-155,180-183,184-187 \\
430-436,437-438,455-458,460-464 \\
464-465,548-553,615-619,666-669 \\
853-856,878-880,896-900,1061-1064\end{array}$ & \\
\hline \multirow[t]{2}{*}{ HSV-2 TK } & \multirow[t]{2}{*}{ ACV } & \multirow{2}{*}{$\begin{array}{l}\text { R34C, R51W, G56E, G59P, P85S, N100H, Q105P, T131P, } \\
\text { R177W, S182D, S182N, V192M, T202A, R217H, R221H, } \\
\text { R221C, R223H, L228I,D229H, R272V, P273S, D274R, } \\
\text { T288M,C337Y }\end{array}$} & \multirow{2}{*}{$\begin{array}{l}\text { A28, L69, D137, Q222, } \\
\text { Y240, T264 }\end{array}$} & \multirow{2}{*}{$\begin{array}{l}215-217,219-222222,439-440,452 \\
467,519-521,551-556,586-591 \\
626-628,808-812\end{array}$} & $R 272 V+P 273 S+D 74 R$ \\
\hline & & & & & $\mathrm{P} 85 \mathrm{~S}+\mathrm{N} 100 \mathrm{H}+\mathrm{V} 192 \mathrm{M}$ \\
\hline \multirow[t]{10}{*}{ HSV-1 DNA pol } & \multirow[t]{3}{*}{ ACV } & \multirow{3}{*}{$\begin{array}{l}\text { D368A, E370A, V462A, K532T, Y557S, Q570R, D581A, } \\
\text { G597KJD, A605V, Q618H, Y696H, R700G, L702H, V714M, } \\
\text { V715M, F716L, A719V/T, S724N,E771Q, L774F, L778M, } \\
\text { D780N, L782I, P797T, E798K, L802F, V183M, } \\
\text { N815L/S/TN/Y/E, Y818C, T821M, G841S/C, R842S, } \\
\text { S889A, F891C/Y, V892S, D907V, I922N/T, Y941H, V958L, } \\
\text { R959H, N961K, D1070N }\end{array}$} & & & $A 719 V+V 904 M$ \\
\hline & & & & & $\mathrm{A} 327 \mathrm{~T}+\mathrm{A} 605 \mathrm{~V}$ \\
\hline & & & & & $\mathrm{T} 566 \mathrm{~A}+\mathrm{A} 605 \mathrm{~V}$ \\
\hline & \multirow[t]{3}{*}{ FCV } & \multirow{3}{*}{$\begin{array}{l}\text { N494S, A605V, F716L, A719V,A719T, S724N, L778M, } \\
\text { D780N, L782I, E798K, F891C, D907V, V958L }\end{array}$} & & & $A 719 V+V 904 M$ \\
\hline & & & & & $\mathrm{A} 327 \mathrm{~T}+\mathrm{A} 605 \mathrm{~V}$ \\
\hline & & & & & $S 724 N+A 916 V$ \\
\hline & CDV & A136T, R700H, R700M, S724N, T821M, L1007H, I1028T & & & \\
\hline & \multirow[t]{2}{*}{$\mathrm{ACV}+\mathrm{FCV}$} & \multirow{2}{*}{$\begin{array}{l}\text { A605V, F716L, A719V, A719T, S724N, L778M, D780N, } \\
\text { L782I, E798K, F891C, D907V, V958L }\end{array}$} & & & $A 719 V+V 904 M$ \\
\hline & & & & & $\mathrm{A} 327 \mathrm{~T}+\mathrm{A} 605 \mathrm{~V}$ \\
\hline & $\mathrm{ACV}+\mathrm{CDV}$ & T821M & & & \\
\hline \multirow[t]{3}{*}{ HSV-2 DNA pol } & ACV & E250Q, R628C, E678G, A724V, S725G, D785N, D912N/N & & & \\
\hline & FCV & S725G, S729N, L783M, D912V & & & \\
\hline & $\mathrm{ACV}+\mathrm{FCV}$ & S725G, D912V & & & \\
\hline
\end{tabular}

a The number is the amino acid position in the protein. The two letters correspond respectively to the wild type amino acid and the mutated amino acid.

bucleotide numbering TK: thymidine kinase, DNA pol: DNA polymerase, ACV: aciclovir, FCV: foscarnet, CDV: cidofovir. 
Accordingly, 95\% of clinical isolates exhibiting acyclovir resistance harbor mutations in UL23 gene $[61,62]$.

Resistance may be suspected when lesions persist for more than 1 week after initiating antiviral treatment or the emergence of new satellite lesions during treatment. A virological confirmation helps health care professionals choose among different treatment options while it avoids the selection of multidrug-resistant strains [63].

Resistance can be assessed by the detection of specific mutations in UL23 or UL30 genes conferring resistance to antiviral drugs (genotypic assays) or by testing a virus against antiviral agents (phenotypic assays). Because most resistance cases are due to TK deficiency or to defective TK activity, mutations in the UL23 gene should be tested first. Genotypic assays consist of the comparison of UL23 and UL30 genes sequences with the whole panel of mutations described in the literature (Table 9) [61-67]. To be useful in clinical practice, it is essential to be able to discriminate between random variations (polymorphism) and true drug resistance mutations. Therefore, when possible, it is best to test in parallel strains collected before and on antiviral therapy. Before starting genotypic assays, an estimation of the viral load should be obtained because the amplification may be hampered at low levels, especially for the UL30 gene that has been shown to need more than 4.5 and $5.5 \log 10$ copies $/ \mathrm{ml}$ for HSV-1 and HSV-2 respectively. Virus isolation in cell culture may be required to increase the input of DNA material [64]. However amplification in cell culture can alter the population balance in the native sample.

Phenotypic assays are based on the measurement of virus growth inhibition in the presence of antiviral drugs. Various concentrations of virus are incubated with various concentrations of antiviral drugs, and the determination of the reduction of virus-induced cytopathic effect or plaque formation compared to a reference strain or the strain isolated before treatment enables the measurement of viral susceptibility to antiviral drugs. The gold standard phenotypic method for the evaluation of HSV susceptibility is the plaque reduction assay $[60,62]$.

Although TK is not essential for growth in cell culture, it is important for viral pathogenesis, particularly for reactivation from latently infected trigeminal ganglia in animal models $[68,69]$. This feature has likely minimized the development of TK based resistance in the immunocompetent community. In patients with ACV resistant strain, cessation of antiviral treatment results in reversion of HSV isolates to ACV sensitivity [70]. The most frequent strains reactivated after an episode caused by a resistant HSV strain are thus ACV-sensitive [70]. However reactivation of some TK-negative HSV clinical isolates have been reported [71,72]. Therefore, despite an initial antiviral efficacy, the same resistance will likely be selected as the previous episode and $\mathrm{ACV}$ treatment may fail, especially if the immunosuppression condition remained.

\section{Conclusion}

Laboratory confirmation of clinically suspected genital herpes diagnosis is necessary. In addition to helping the therapeutic management of ulcerative genital lesions and herpes diagnosis, it helps identify persons at risk of transmitting infection. Direct diagnosis is recommended and validated molecular assays are a good alternative to cell culture. Indirect diagnosis should use only FDA or $\mathrm{CE}$ approved type-specific serology based on glycoprotein G1 and G2 antigens and has to be considered for recurrent genital symptoms or atypical symptoms without laboratory confirmation and for testing pregnant women at risk of acquiring HSV infection.

\section{Competing interests}

The authors declare that they have no competing interests.

\section{Authors' contributions}

$J \mathrm{~L}$ and $L B$ performed literature searches and drafted the manuscript. HP participated in editing the manuscript. All authors read and approved the final manuscript.

\section{Acknowledgement}

We are indebted to Amy Penn (Global Health Sciences, USCF, San Francisco, USA) for her carefully review of the manuscript and her corrections.

\section{Author details}

'Université Paris Diderot, Sorbonne Paris Cité, Microbiology laboratory, Inserm U941, Hôpital Saint-Louis, APHP, 1 Avenue Claude Vellefaux, Paris 75010, France. ${ }^{2}$ Laboratoire de Microbiologie, hôpital Européen Georges Pompidou, Assistance Publique-Hôpitaux de Paris, Sorbonne Paris Cité, Paris, France. ${ }^{3}$ Faculté de Médecine Paris Descartes, Université Paris Descartes (Paris V), Sorbonne Paris Cité, Paris, France.

Received: 30 January 2014 Accepted: 1 May 2014 Published: 12 May 2014

\section{References}

1. Whitley RJ, Roizman B: Herpes simplex virus infections. Lancet 2001, 357:1513-1518.

2. McGeoch DJ, Moss HW, McNab D, Frame MC: DNA sequence and genetic content of the HindIII I region in the short unique component of the herpes simplex virus type 2 genome: identification of the gene encoding glycoprotein G, and evolutionary comparisons. J Gen Virol 1987, 68(Pt 1):19-38.

3. Tunbäck P, Bergström T, Löwhagen G-B, Hoebeke J, Liljeqvist J-A: Type-specific reactivity of anti-glycoprotein $\mathrm{G}$ antibodies from herpes simplex virus-infected individuals is maintained by single or dual typespecific residues. J Gen Virol 2005, 86(Pt 2):247-251.

4. Burrows J, Nitsche A, Bayly B, Walker E, Higgins G, Kok T: Detection and subtyping of Herpes simplex virus in clinical samples by LightCycler PCR, enzyme immunoassay and cell culture. BMC Microbiol 2002, 2:12.

5. Legoff J, Bouhlal H, Grésenguet $G$, Weiss H, Khonde N, Hocini H, Désiré N, Si-Mohamed A, de Dieu Longo J, Chemin C, Frost E, Pépin J, Malkin J-E, Mayaud P, Bélec L: Real-time PCR quantification of genital shedding of herpes simplex virus (HSV) and human immunodeficiency virus (HIV) in women coinfected with HSV and HIV. J Clin Microbiol 2006, 44:423-432.

6. Gupta R, Warren T, Wald A: Genital herpes. Lancet 2007, 370:2127-2137.

7. Bernstein DI, Bellamy AR, Hook EW 3rd, Levin MJ, Wald A, Ewell MG, Wolff PA, Deal CD, Heineman TC, Dubin G, Belshe RB: Epidemiology, clinical presentation, and antibody response to primary infection with herpes simplex virus type 1 and type 2 in young women. Clin Infect Dis 2013, 56:344-351 
8. Brown ZA, Wald A, Morrow RA, Selke S, Zeh J, Corey L: Effect of serologic status and cesarean delivery on transmission rates of herpes simplex virus from mother to infant. JAMA 2003, 289:203-209.

9. Brown EL, Gardella C, Malm G, Prober CG, Forsgren M, Krantz EM, Arvin AM, Yasukawa LL, Mohan K, Brown Z, Corey L, Wald A: Effect of maternal herpes simplex virus (HSV) serostatus and HSV type on risk of neonatal herpes. Acta Obstet Gynecol Scand 2007, 86:523-529.

10. Wald A, Zeh J, Selke S, Warren T, Ryncarz AJ, Ashley R, Krieger JN, Corey L: Reactivation of genital herpes simplex virus type 2 infection in asymptomatic seropositive persons. N Engl J Med 2000, 342:844-850.

11. Tronstein E, Johnston C, Huang M-L, Selke S, Magaret A, Warren T, Corey L, Wald A: Genital shedding of herpes simplex virus among symptomatic and asymptomatic persons with HSV-2 infection. JAMA 2011, 305:1441-1449.

12. Corey L, Wald A: Genital Herpes. In Sexually Transmitted Diseases. 4th edition. Edited by Holmes KK, Sparling PF, Stamm WE, Piot P, Wasserheit JW, Corey L, Cohen M. New York: McGraw Hill; 2008:399-437.

13. DiCarlo RP, Martin DH: The clinical diagnosis of genital ulcer disease in men. Clin Infect Dis 1997, 25:292-298.

14. Cusini M, Ghislanzoni M: The importance of diagnosing genital herpes. J Antimicrob Chemother 2001, 47 Suppl T1:9-16.

15. Lautenschlager S, Eichmann A: Urethritis: an underestimated clinical variant of genital herpes in men? J Am Acad Dermatol 2002, 46:307-308.

16. Bergström T, Vahlne A, Alestig K, Jeansson S, Forsgren M, Lycke E: Primary and recurrent herpes simplex virus type 2 -induced meningitis. J Infect Dis 1990, 162:322-330.

17. Kimberly A, Workowski MD, Levine WC: Sexually transmitted diseases treatment guidelines 2002. Centers for Disease Control and Prevention. MMWR Recomm Rep 2002, 51:1-78.

18. Domeika M, Bashmakova M, Savicheva A, Kolomiec N, Sokolovskiy E, Hallen A, Unemo M, Ballard RC, Eastern European Network for Sexual and Reproductive Health (EE SRH Network): Guidelines for the laboratory diagnosis of genital herpes in eastern European countries. Euro Surveill 2010, 15.

19. Van Wagoner NJ, Hook EW 3rd: Herpes diagnostic tests and their use. Curr Infect Dis Rep 2012, 14:175-184.

20. Simmons A: Clinical manifestations and treatment considerations of herpes simplex virus infection. J Infect Dis 2002, 186(Suppl 1):S71-77.

21. Debyle C, Bulkow L, Miernyk K, Chikoyak L, Hummel KB, Hennessy T, Singleton R: Comparison of nasopharyngeal flocked swabs and nasopharyngeal wash collection methods for respiratory virus detection in hospitalized children using real-time polymerase chain reaction. J Virol Methods 2012, 185:89-93.

22. Dezzutti CS, Hendrix CW, Marrazzo JM, Pan Z, Wang L, Louissaint N, Kalyoussef S, Torres NM, Hladik F, Parikh U, Mellors J, Hillier SL, Herold BC: Performance of swabs, lavage, and diluents to quantify biomarkers of female genital tract soluble mucosal mediators. PLoS One 2011, 6:e23136.

23. Walsh P, Overmyer CL, Pham K, Michaelson S, Gofman L, DeSalvia L, Tran T, Gonzalez D, Pusavat J, Feola M, lacono KT, Mordechai E, Adelson ME: Comparison of respiratory virus detection rates for infants and toddlers by use of flocked swabs, saline aspirates, and saline aspirates mixed in universal transport medium for room temperature storage and shipping. J Clin Microbiol 2008, 46:2374-2376.

24. Crane LR, Gutterman PA, Chapel T, Lerner AM: Incubation of swab materials with herpes simplex virus. J Infect Dis 1980, 141:531.

25. Legoff J, Tanton C, Lecerf M, Grésenguet G, Nzambi K, Bouhlal H, Weiss H, Belec L, ANRS1212 Study Group: Influence of storage temperature on the stability of HIV-1 RNA and HSV-2 DNA in cervicovaginal secretions collected by vaginal washing. J Virol Methods 2006, 138:196-200.

26. Wald A, Huang M-L, Carrell D, Selke S, Corey L: Polymerase chain reaction for detection of herpes simplex virus (HSV) DNA on mucosal surfaces: comparison with HSV isolation in cell culture. J Infect Dis 2003, 188:1345-1351.

27. Strick $L B$, Wald $A$ : Diagnostics for herpes simplex virus: is $P C R$ the new gold standard? Mol Diagn Ther 2006, 10:17-28.

28. Ustaçelebi S: Diagnosis of herpes simplex virus infections. J Clin Virol 2001, 21:255-259.

29. Bonville CA, Forbes BA, Bartholoma N, McMillan JA, Weiner LB: Rapid detection of herpes simplex virus in MRC- 5 cells using low-speed centrifugation enhancement and immunoperoxidase staining $16 \mathrm{~h}$ post-inoculation. Diagn Microbiol Infect Dis 1987, 8:251-254.
30. Winter GF, Inglis JM, Cubie HA: Rapid diagnosis of herpes simplex virus infections in conventional and shell vial cell cultures using monoclonal antibodies. J Virol Methods 1987, 15:329-330.

31. Stabell EC, Olivo PD: Isolation of a cell line for rapid and sensitive histochemical assay for the detection of herpes simplex virus. J Virol Methods 1992, 38:195-204.

32. Stabell EC, O'Rourke SR, Storch GA, Olivo PD: Evaluation of a genetically engineered cell line and a histochemical beta-galactosidase assay to detect herpes simplex virus in clinical specimens. J Clin Microbiol 1993, 31:2796-2798

33. Hobson A, Wald A, Wright N, Corey L: Evaluation of a quantitative competitive PCR assay for measuring herpes simplex virus DNA content in genital tract secretions. J Clin Microbiol 1997, 35:548-552.

34. Mbopi-Kéou FX, Grésenguet G, Mayaud P, Weiss HA, Gopal R, Matta M, Paul $J$, Brown DW, Hayes RJ, Mabey DC, Bélec L: Interactions between herpes simplex virus type 2 and human immunodeficiency virus type 1 infection in African women: opportunities for intervention. J Infect Dis 2000, 182:1090-1096.

35. Ryncarz AJ, Goddard J, Wald A, Huang ML, Roizman B, Corey L: Development of a high-throughput quantitative assay for detecting herpes simplex virus DNA in clinical samples. J Clin Microbiol 1999, 37:1941-1947

36. Espy MJ, Uhl JR, Mitchell PS, Thorvilson JN, Svien KA, Wold AD, Smith TF: Diagnosis of herpes simplex virus infections in the clinical laboratory by LightCycler PCR. J Clin Microbiol 2000, 38:795-799.

37. Whiley DM, Mackay IM, Syrmis MW, Witt MJ, Sloots TP: Detection and differentiation of herpes simplex virus types 1 and 2 by a duplex LightCycler PCR that incorporates an internal control PCR reaction. J Clin Virol 2004, 30:32-38.

38. Meylan S, Robert D, Estrade C, Grimbuehler V, Péter O, Meylan PR, Sahli R: Real-time PCR for type-specific identification of herpes simplex in clinical samples: evaluation of type-specific results in the context of CNS diseases. J Clin Virol 2008, 41:87-91.

39. Adelson ME, Feola M, Trama J, Tilton RC, Mordechai E: Simultaneous detection of herpes simplex virus types 1 and 2 by real-time PCR and Pyrosequencing. J Clin Virol 2005, 33:25-34.

40. Fang XF, Song B, Tu YY, Tong JZ, Faul $J L$, Bai H: Rapid detection of glycoprotein $\mathrm{G}$ gene for the diagnosis and typing of herpes simplex virus infection in genital herpes. Sex Transm Infect 1999, 75:396-397.

41. Geretti AM: Genital herpes. Sex Transm Infect 2006, 82 Suppl 4:iv31-34.

42. Geretti AM, Brown DW: National survey of diagnostic services for genital herpes. Sex Transm Infect 2005, 81:316-317.

43. Ramaswamy M, McDonald C, Smith M, Thomas D, Maxwell S, TenantFlowers M, Geretti AM: Diagnosis of genital herpes by real time PCR in routine clinical practice. Sex Transm Infect 2004, 80:406-410.

44. Scoular A, Gillespie G, Carman WF: Polymerase chain reaction for diagnosis of genital herpes in a genitourinary medicine clinic. Sex Transm Infect 2002, 78:21-25.

45. Kim H-J, Tong $Y$, Tang W, Quimson L, Cope VA, Pan X, Motre A, Kong R, Hong J, Kohn D, Miller NS, Poulter MD, Kong H, Tang Y-W, Yen-Lieberman B: $A$ rapid and simple isothermal nucleic acid amplification test for detection of herpes simplex virus types 1 and 2. J Clin Virol 2011, 50:26-30.

46. Selvaraju SB, Wurst M, Horvat RT, Selvarangan R: Evaluation of three analyte-specific reagents for detection and typing of herpes simplex virus in cerebrospinal fluid. Diagn Microbiol Infect Dis 2009, 63:286-291.

47. Van Der Pol B, Warren T, Taylor SN, Martens M, Jerome KR, Mena L, Lebed J, Ginde S, Fine P, Hook EW 3rd: Type-specific identification of anogenital herpes simplex virus infections by use of a commercially available nucleic acid amplification test. J Clin Microbiol 2012, 50:3466-3471.

48. Wald A, Ashley-Morrow R: Serological testing for herpes simplex virus (HSV)-1 and HSV-2 infection. Clin Infect Dis 2002, 35(Suppl 2):S173-182.

49. Ashley RL: Sorting out the new HSV type specific antibody tests. Sex Transm Infect 2001, 77:232-237.

50. Slomka MJ, Ashley RL, Cowan FM, Cross A, Brown DW: Monoclona antibody blocking tests for the detection of HSV-1- and HSV-2-specific humoral responses: comparison with western blot assay. J Virol Methods 1995, 55:27-35.

51. LeGoff J, Mayaud P, Gresenguet G, Weiss HA, Nzambi K, Frost E, Pepin J, Belec L, ANRS 12-12 Study Group: Performance of HerpeSelect and Kalon assays in detection of antibodies to herpes simplex virus type 2 . J Clin Microbiol 2008, 46:1914-1918. 
52. Daikoku T, Horiba K, Kawana T, Hirano M, Shiraki K: Novel deletion in glycoprotein $\mathrm{G}$ forms a cluster and causes epidemiologic spread of herpes simplex virus type 2 infection. J Med Virol 2013, 85:1818-1828.

53. Liljeqvist JA, Svennerholm B, Bergström T: Herpes simplex virus type 2 glycoprotein G-negative clinical isolates are generated by single frameshift mutations. J Virol 1999, 73:9796-9802.

54. Ashley RL, Wu L, Pickering JW, Tu MC, Schnorenberg L: Premarket evaluation of a commercial glycoprotein G-based enzyme immunoassay for herpes simplex virus type-specific antibodies. J Clin Microbiol 1998, 36:294-295.

55. Morrow RA, Friedrich D, Krantz E: Performance of the focus and Kalon enzyme-linked immunosorbent assays for antibodies to herpes simplex virus type 2 glycoprotein $\mathrm{G}$ in culture-documented cases of genital herpes. J Clin Microbiol 2003, 41:5212-5214.

56. Biraro S, Mayaud P, Morrow RA, Grosskurth H, Weiss HA: Performance of commercial herpes simplex virus type- 2 antibody tests using serum samples from Sub-Saharan Africa: a systematic review and meta-analysis. Sex Transm Dis 2011, 38:140-147.

57. Van Dyck E, Buvé A, Weiss HA, Glynn JR, Brown DWG, De Deken B, Parry J, Hayes RJ: Performance of commercially available enzyme immunoassays for detection of antibodies against herpes simplex virus type 2 in African populations. J Clin Microbiol 2004, 42:2961-2965.

58. Ross $K$, Johnston C, Wald A: Herpes simplex virus type 2 serological testing and psychosocial harm: a systematic review. Sex Transm Infect 2011, 87:594-600.

59. Delaney S, Gardella C, Daruthayan C, Saracino M, Drolette L, Corey L, Wald A: A prospective cohort study of partner testing for herpes simplex virus and sexual behavior during pregnancy. J Infect Dis 2012, 206:486-494.

60. Piret J, Boivin G: Resistance of herpes simplex viruses to nucleoside analogues: mechanisms, prevalence, and management. Antimicrob Agents Chemother 2011, 55:459-472.

61. Bacon TH, Levin MJ, Leary JJ, Sarisky RT, Sutton D: Herpes simplex virus resistance to acyclovir and penciclovir after two decades of antiviral therapy. Clin Microbiol Rev 2003, 16:114-128.

62. Morfin F, Thouvenot D: Herpes simplex virus resistance to antiviral drugs J Clin Virol 2003, 26:29-37.

63. Andrei G, Georgala A, Topalis D, Fiten P, Aoun M, Opdenakker G, Snoeck R: Heterogeneity and evolution of thymidine kinase and DNA polymerase mutants of herpes simplex virus type 1: implications for antiviral therapy. J Infect Dis 2013, 207:1295-1305.

64. Burrel S, Deback C, Agut H, Boutolleau D: Genotypic characterization of UL23 thymidine kinase and UL30 DNA polymerase of clinical isolates of herpes simplex virus: natural polymorphism and mutations associated with resistance to antivirals. Antimicrob Agents Chemother 2010, 54:4833-4842.

65. Sauerbrei A, Deinhardt S, Zell R, Wutzler P: Phenotypic and genotypic characterization of acyclovir-resistant clinical isolates of herpes simplex virus. Antiviral Res 2010, 86:246-252

66. Sauerbrei A, Liermann K, Bohn K, Henke A, Zell R, Gronowitz S, Wutzler P: Significance of amino acid substitutions in the thymidine kinase gene of herpes simplex virus type 1 for resistance. Antiviral Res 2012, 96:105-107.

67. Wang Y, Wang Q, Zhu Q, Zhou R, Liu J, Peng T: Identification and characterization of acyclovir-resistant clinical HSV-1 isolates from children. J Clin Virol 2011, 52:107-112

68. Chen S-H, Pearson A, Coen DM, Chen S-H: Failure of thymidine kinasenegative herpes simplex virus to reactivate from latency following efficient establishment. J Viro/ 2004, 78:520-523.

69. Coen DM, Kosz-Vnenchak M, Jacobson JG, Leib DA, Bogard CL, Schaffer PA Tyler KL, Knipe DM: Thymidine kinase-negative herpes simplex virus mutants establish latency in mouse trigeminal ganglia but do not reactivate. Proc Natl Acad Sci U S A 1989, 86:4736-4740.

70. Kriesel JD, Spruance SL, Prichard M, Parker JN, Kern ER: Recurrent antiviralresistant genital herpes in an immunocompetent patient. $J$ Infect Dis 2005, 192:156-161.
71. Horsburgh BC, Chen SH, Hu A, Mulamba GB, Burns WH, Coen DM: Recurrent acyclovir-resistant herpes simplex in an immunocompromised patient: can strain differences compensate for loss of thymidine kinase in pathogenesis? J Infect Dis 1998, 178:618-625.

72. Morfin F, Thouvenot D, Aymard M, Souillet G: Reactivation of acyclovirresistant thymidine kinase-deficient herpes simplex virus harbouring single base insertion within a $7 \mathrm{Gs}$ homopolymer repeat of the thymidine kinase gene. J Med Virol 2000, 62:247-250.

doi:10.1186/1743-422X-11-83

Cite this article as: LeGoff et al:: Diagnosis of genital herpes simplex virus infection in the clinical laboratory. Virology Journal 2014 11:83.

\section{Submit your next manuscript to BioMed Central and take full advantage of:}

- Convenient online submission

- Thorough peer review

- No space constraints or color figure charges

- Immediate publication on acceptance

- Inclusion in PubMed, CAS, Scopus and Google Scholar

- Research which is freely available for redistribution
C Biomed Central 